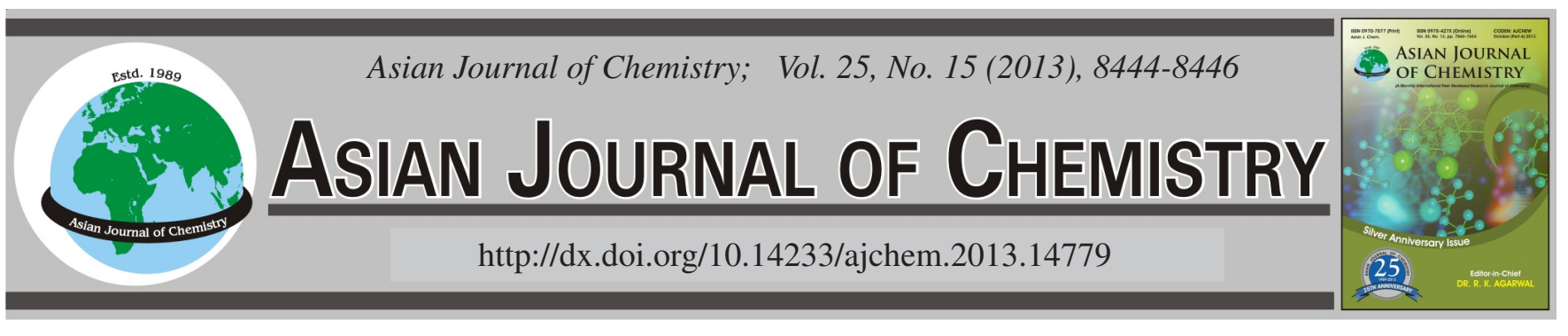

\title{
Synthesis, Characterization and Antibacterial Activities of Manganese(II), Nickel(II), Copper(II) and Zinc(II) Complexes of the Hydrazone Compounds Derived from 1-Phenyl-3-methyl-4-acyl-pyrazole and Benzoyl Hydrazine
}

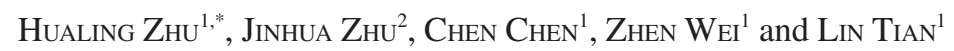

${ }^{1}$ Department of Basic Science, Tianjin Agricultural College, Tianjin, P.R. China

${ }^{2}$ Meteorological Service Center of Shanxi Province, Taiyuan, P.R. China

*Corresponding author: E-mail: zhuhualing2004@126.com

\begin{abstract}
Manganese(II), nickel(II), copper(II) and zinc(II) complexes were prepared by the reactions of the correspondence metal acetate and the hydrazone ligands $\left(\mathrm{L}_{1}-\mathrm{L}_{3}\right)$ derived from 1-phenyl-3-methyl-4-acyl-pyrazole and benzoyl hydrazine. The ligands $\left(\mathrm{L}_{1}-\mathrm{L}_{3}\right)$ and metal complexes were characterized by elemental analysis and spectroscopic techniques such as ${ }^{1} \mathrm{H} N M R$ and IR. Antimicrobial activity studies of $\left(\mathrm{L}_{1}-\mathrm{L}_{3}\right)$ and the metal complexes against Escherichia coli and Bacillus subtilis were carried out by using disc diffusion method. The results indicate that the free ligands are more or less inactive against the two bacteria, the antibacterial abilities of the ligands become more pronounced when they are coordinated to the metal ions. The copper(II) complex of the benzoic acid [1-(5-methyl-3-oxo-2-phenyl-2,3-dihydro- $1 H$-pyrazol-4yl)ethylidene]hydrazide $\left(\mathrm{L}_{1}\right)$ shows a signiûcant inhibition to the growth of the two tested bacteria.
\end{abstract}

Key Words: Synthesis, Characterization, Complex, Antibacterial activity.

\section{INTRODUCTION}

Besides the good insecticidal activity and phytocidal activity, aryl pyrazole derivatives have strong inhibition to the activities of the atpase and mitochondrial enzyme in the process of the life ${ }^{1}$. Some aryl pyrazole derivatives such as antipyrine, aminopyrine and analgin, have been widely used in human and livestock medicine to treat headache, fever, rheumatalgia etc. $^{2}$. Derivatives of 1-phenyl-3-methyl-4-acyl-pyrazole have been found extensive application in coordination chemistry ${ }^{3}$ and in antibacterial activation ${ }^{4,5}$. Hydrazones derived from the condensation reactions of hydrazides with aldehydes or ketones show excellent biological properties, such as antimicrobial ${ }^{6}$, anticancer $^{7}$ and antimalarial ${ }^{8}$ activities. The possible properties and using of hydrazones and the 1-phenyl-3-methyl-4-acylpyrazole derivatives make it attractive to study these compounds. The present work deals with the synthesis and antimicrobial activities of the complexes and the hydrazone ligands $\left(\mathrm{L}_{1}-\mathrm{L}_{3}\right)$ derived from 1-phenyl-3-methyl-4-acyl-pyrazole and benzoyl hydrazine (Fig. 1).

\section{EXPERIMENTAL}

All chemicals and solvents were of analytical grade. Compound 1-phenyl-3-methyl-4-acetyl-5-pyrazolone (a) and 1-phenyl-3-methyl-4-(2-thenoyl)pyrazolone (c) were synthesized according to the literature ${ }^{9}$. Compound 4-formacyl5-methyl-3-chloro-2-phenyl-2H-pyrazole (b) was synthesized according to the literature ${ }^{10}$. IR spectra were recorded $(\mathrm{KBr}$ disks) on a Perkin-Elmer FTIR spectrometer. ${ }^{1} \mathrm{H}$ NMR spectra were obtained on a Bruker $200 \mathrm{MHz}$ spectrometer. A CarloErba 1106 Elemental Analyser was utilized for elemental analysis.

Synthesis of the ligands $\left(\mathrm{L}_{1}-\mathrm{L}_{3}\right)$ : The ligands $\left(\mathrm{L}_{1}-\mathrm{L}_{3}\right)$ were synthesized by refluxing the mixture of 1-phenyl-3- methyl4-acetyl-5-pyrazolone (a)/4-formacyl-5-methyl-3-chloro-2phenyl-2H-pyrazole (b)/1-phenyl-3-methyl-4-(2-thenoyl)pyrazolone (c) $(30 \mathrm{~m} \mathrm{~mol})$ and benzoyl hydrazine $(30 \mathrm{~m} \mathrm{~mol})$ in ethanol $(150 \mathrm{~mL})$ over a steam bath for $6 \mathrm{~h}$, then the solution was cooled down to room temperature. After 7 days, crystal was obtained and recrystallized from ethanol, finally dried in a vacuum desiccator.

2-Methyl-penta-2,4-dienoic acid [1-(5-methyl-3-oxo-2phenyl-2,3-dihydro-1H-pyrazol-4-yl)ethylidene]hydrazide (L): White, yield: $83 \%$, m.p. $247 \pm 1{ }^{\circ} \mathrm{C}$. H NMR (200 MHz, DMF): 7.75 (s, 1H, O=C-NH), 7.14-7.74 (m, 10H, phenyl), $2.49\left(\mathrm{~m}, 1 \mathrm{H}\right.$, pyrazol-NH), $1.72\left(\mathrm{~d}, 3 \mathrm{H}\right.$, pyrazol- $\left.\mathrm{CH}_{3}\right), 0.93$ (s, $\left.3 \mathrm{H}, \mathrm{CH}_{3}-\mathrm{C}=\mathrm{N}\right)$.

2-[N2-(5-Chloro-3-methyl-1-phenyl-1H-pyrazol-4ylmethylene)-hydrazino]-1-phenyl-ethanone $\left(\mathbf{L}_{2}\right)$ : Yellow, yield: $93 \%$, m.p. $176 \pm 1{ }^{\circ} \mathrm{C}$. H NMR (200 MHz, DMF): 8.06 

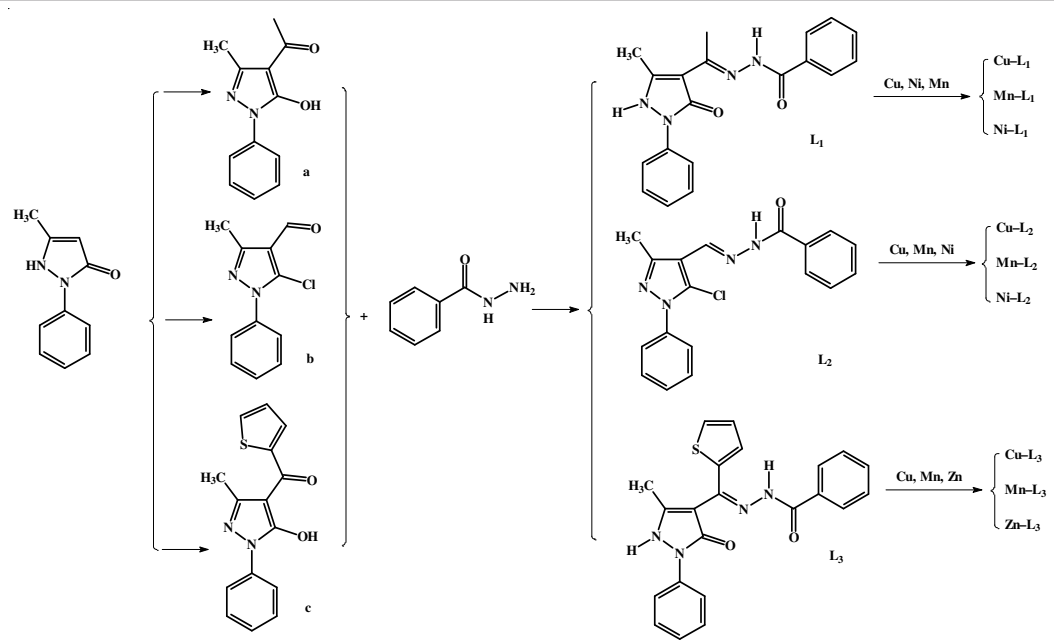

Fig. 1. Main synthesis route of the ligands and the metal complexes

(s, 1H, O=C-NH), 7.21-7.96 (m, 10H, phenyl), $5.12(\mathrm{~s}, 1 \mathrm{H}$, $\mathrm{H}-\mathrm{C}=\mathrm{N}), 1.83\left(\mathrm{~d}, 3 \mathrm{H}\right.$, pyrazol- $\left.\mathrm{CH}_{3}\right)$.

Benzoic acid [(5-methyl-3-oxo-2-phenyl-2,3-dihydro$1 \boldsymbol{H}$-pyrazol-yl)thiophen-2-yl-methylene]hydrazide $\left(\mathrm{L}_{3}\right)$ : Pale yellow, yield: $90 \%$, m.p. $224 \pm 1{ }^{\circ} \mathrm{C}$. H NMR (200 MHz, DMF): 8.02-8.07(m, 3H, thiophen ring), 7.77 (s, 1H, O=C$\mathrm{NH}), 7.24-7.76(\mathrm{~m}, 10 \mathrm{H}$, phenyl), 3.57 (, $1 \mathrm{H}$, pyrazol- $\mathrm{NH})$, $1.83\left(\mathrm{~d}, 3 \mathrm{H}\right.$, pyrazol- $\left.\mathrm{CH}_{3}\right)$.

Synthesis of the metal complexes: $25 \mathrm{~mL}$ ethanol solution containing $1 \mathrm{mmol} \mathrm{M}(\mathrm{Ac})_{2}(\mathrm{M}=\mathrm{Cu}, \mathrm{Mn}, \mathrm{Ni}, \mathrm{Zn})$ was dropped in the solution of $2 \mathrm{mmol}$ ligand $\left(\mathrm{L}_{1}-\mathrm{L}_{3}\right)$ with $30 \mathrm{~mL}$ ethanol. The mixture was stirred and refluxed for about $4 \mathrm{~h}$. After $4 \mathrm{~h}$, the solution was cooled down to room temperature and the precipitate was filtered off. The precipitate was washed with ethanol and then dried in vacuum. All the complexes were prepared by the same method and isolated as powder material. Though all the four metal complexes of each ligand were tried to prepared, only three of them were obtained.

Antimicrobial activities: The antibacterial activity tests of the ligand and the metal complexes at different concentrations against Escherichia coli and Bacillus subtilis were performed using disc diffusion method. Each compound was dissolved in DMF and was made into quantificational medicine sensitive pieces at different concentration, then the medicine sensitive pieces were put into the culture dish with equal culture medium and Bacterial inoculum, The bacteria were incubated in constant temperature incubator at $37^{\circ} \mathrm{C}$ for $24 \mathrm{~h}$. All experiments were performed three times parallelly. The diameter data of inhibition zone of the ligands and complexes was measured and averaged.

\section{RESULTS AND DISCUSSION}

The ligands $\left(\mathrm{L}_{1}-\mathrm{L}_{3}\right)$ (Fig. 1) were synthesized in a twostep process in which the 1-phenyl-3-methyl-4-acyl-pyrazole (a-c) were firstly synthesized according to the literature. In the second step, the ligands were obtained by reaction of benzoyl hydrazine with an appropriate 1-phenyl-3-methyl-4acyl-pyrazole (a-c) by refluxing in absolute ethanol. The ligands $\left(\mathrm{L}_{1}-\mathrm{L}_{3}\right)$ and their metal complexes were characterized by infrared spectra, ${ }^{1} \mathrm{H}$ NMR and elemental analyses. The newly synthesized ligands and their metal complexes are stable at room temperature in the solid state. The ligands and its metal complexes are generally soluble in EtOH, DMF and DMSO. Physical properties, element analysis data are reported in Table1. The analytical data of all the synthesized complexes shows that the complexes are composed by the 2:1 rate of ligand and metal iron.

Spectroscopic characterization: The ${ }^{1} \mathrm{H}$ NMR data for ligands showed the signals at 7.14-7.74 in the H NMR specta of $\mathrm{L}_{1}$ were assigned to the ten protons of two phenyl group. The singlet at $7.75 \mathrm{ppm}$ was attributed to the proton of the acylamino group. The signal of the $\mathrm{NH}$ proton in the pyrazol ring was observed at $2.49 \mathrm{ppm}$, there is no obvious signals of $\mathrm{OH}$ which showed the ligand of $\mathrm{L}_{1}$ existed in imine-keto form.

The ${ }^{1} \mathrm{H}$ NMR spectra of $\mathrm{L}_{2}$ showed a singlet at $5.12 \mathrm{ppm}$ and a singlet at $8.06 \mathrm{ppm}$ belonging to the proton of $\mathrm{H}-\mathrm{C}=\mathrm{N}$ and $\mathrm{O}=\mathrm{C}-\mathrm{NH}$ group, respectively. The peaks between 7.21 and $7.96 \mathrm{ppm}$ were assigned to the aromatic protons. The double signals at 1.83 belonged to the three protons of the methyl boned to the pyrazol ring.

The signals at 7.24-7.76 ppm in the ${ }^{1} \mathrm{H}$ NMR spectra of $\mathrm{L}_{3}$ were assigned to the aromatic protons. The signal of the $\mathrm{NH}$ proton in the pyrazol ring was observed at $3.57 \mathrm{ppm}$, there was no obvious signal of $\mathrm{OH}$ which showed the ligand of $\mathrm{L}_{3}$ existed in imine-keto form. The signals at 8.02-8.07 ppm and the singlet at $7.77 \mathrm{ppm}$ belonged to the proton of thiophene ring and $\mathrm{O}=\mathrm{C}-\mathrm{NH}$ group, respectively.

The IR spectra data of the free ligands and the complexes is given in Table- 2 . In the spectra of the ligand $\mathrm{L}_{1}$, bands at 3436,1666 and $1622 \mathrm{~cm}^{-1}$ were attributed to $\mathrm{N}-\mathrm{H}, \mathrm{C}=\mathrm{O}$ and $\mathrm{C}=\mathrm{N}$, respectively. These bands switched to lower wave number after coordination of the ligand to the metal iron through the atom nitrogen of the $\mathrm{C}=\mathrm{N}$, atom nitrogen of the $\mathrm{N}-\mathrm{H}$ and the atom $\mathrm{O}$ of the $\mathrm{C}=\mathrm{O}$, the coordination way was also confirmed by the band at $559-529 \mathrm{~cm}^{-1}$ assigned to $\mathrm{V}(\mathrm{M}-\mathrm{O})$ and the band at $491-439 \mathrm{~cm}^{-1}$ assigned to $\mathrm{v}(\mathrm{M}-\mathrm{N})$.

In the spectra of the ligand $\mathrm{L}_{2}$, bands at 3505,1645 and $1621 \mathrm{~cm}^{-1}$ were attributed to $\mathrm{N}-\mathrm{H}, \mathrm{C}=\mathrm{O}$ and $\mathrm{C}=\mathrm{N}$. Differently, the coordination way of $\mathrm{L}_{2}$ and iron was that the ligand coordinated with the iron only through the atom $\mathrm{O}$ of the $\mathrm{C}=\mathrm{O}$ and atom nitrogen of the $\mathrm{N}-\mathrm{H}$, while the atom nitrogen of the $\mathrm{C}=\mathrm{N}$ did not take part into coordination. All these could be confirmed by only the band of $\mathrm{C}=\mathrm{O}$ and $\mathrm{N}-\mathrm{H}$ switches to lower wave number after coordination, while the band of $\mathrm{C}=\mathrm{N}$ did not change. 
TABLE-1

ANALYTICAL DATA AND PHYSICAL PROPERTIES OF THE LIGANDS AND THE METAL COMPLEXES

\begin{tabular}{|c|c|c|c|c|c|c|}
\hline \multirow{2}{*}{ Compound } & \multirow{2}{*}{ Colour } & \multirow{2}{*}{ m.p. $\left({ }^{\circ} \mathrm{C}\right)$} & \multirow{2}{*}{ Yield (\%) } & \multicolumn{3}{|c|}{ Found (calcd.) \% } \\
\hline & & & & $\mathrm{C}$ & $\mathrm{H}$ & $\mathrm{N}$ \\
\hline $\mathrm{L}_{1}$ & White & $247 \pm 1$ & 83 & $59.54(59.50)$ & $6.87(6.86)$ & $21.37(21.39)$ \\
\hline $\mathrm{Cu}-\mathrm{L}_{1}$ & Yellow & $>360$ & 75 & $53.06(53.08)$ & $6.12(6.10)$ & $19.05(19.05)$ \\
\hline $\mathrm{Ni}-\mathrm{L}_{1}$ & Green & $>360$ & 68 & $53.51(53.49)$ & $6.17(6.18)$ & $19.21(19.22)$ \\
\hline $\mathrm{Mn}-\mathrm{L}_{1}$ & Yellow & $>360$ & 43 & $53.89(53.84)$ & $6.22(6.19)$ & $19.34(19.37)$ \\
\hline $\mathrm{L}_{2}$ & Yellow & $176 \pm 1$ & 93 & $63.81(63.80)$ & $4.43(4.44)$ & $16.54(16.56)$ \\
\hline $\mathrm{Cu}-\mathrm{L}_{2}$ & Brown & $271 \pm 1$ & 87 & $58.30(58.29)$ & $4.05(4.08)$ & $15.11(15.13)$ \\
\hline $\mathrm{Mn}-\mathrm{L}_{2}$ & Brown & $>360$ & 71 & $59.02(58.99)$ & $4.10(4.12)$ & $15.30(15.29)$ \\
\hline $\mathrm{Ni}-\mathrm{L}_{2}$ & Orange & $311 \pm 1$ & 64 & $58.70(58.73)$ & $4.08(4.06)$ & $15.22(15.23)$ \\
\hline $\mathrm{L}_{3}$ & Yellow & $224 \pm 1$ & 90 & $65.12(65.12)$ & 3.88 (3.87) & 14.47 (14.49) \\
\hline $\mathrm{Cu}-\mathrm{L}_{3}$ & Green & $324 \pm 1$ & 82 & $60.14(60.20)$ & $3.58(3.49)$ & $13.37(13.28)$ \\
\hline $\mathrm{Mn}-\mathrm{L}_{3}$ & Yellow & $335 \pm 1$ & 56 & $60.80(60.90)$ & $3.62(3.72)$ & $13.51(13.40)$ \\
\hline $\mathrm{Zn}-\mathrm{L}_{3}$ & Yellow & $329 \pm 1$ & 62 & $60.07(60.10)$ & $3.58(3.44)$ & $13.35(13.45)$ \\
\hline
\end{tabular}

TABLE-2

SELECTED INFRARED SPECTRAL DATA OF

THE LIGANDS AND THE COMPLEXES $\left(\mathrm{cm}^{-1}\right)$

\begin{tabular}{cccccc}
\hline Compound & $v(\mathrm{C}=\mathrm{N})$ & $v(\mathrm{~N}-\mathrm{H})$ & $v(\mathrm{C}=\mathrm{O})$ & $v(\mathrm{M}-\mathrm{N})$ & $v(\mathrm{M}-\mathrm{O})$ \\
\hline $\mathrm{L}_{1}$ & 1622 & 3436 & 1666 & - & - \\
$\mathrm{Cu}-\mathrm{L}_{1}$ & 1621 & 3427 & 1644 & 550 & 466 \\
$\mathrm{Ni}-\mathrm{L}_{1}$ & 1604 & 3415 & 1638 & 559 & 439 \\
$\mathrm{Mn}-\mathrm{L}_{1}$ & 1612 & 3425 & 1639 & 529 & 491 \\
$\mathrm{~L}_{2}$ & 1621 & 3505 & 1645 & - & - \\
$\mathrm{Cu}-\mathrm{L}_{2}$ & 1621 & 3417 & 1630 & 548 & 450 \\
$\mathrm{Mn}-\mathrm{L}_{2}$ & 1621 & 3424 & 1644 & 529 & 500 \\
$\mathrm{Zn}-\mathrm{L}_{2}$ & 1621 & 3425 & 1639 & 599 & 498 \\
$\mathrm{~L}_{3}$ & 1623 & 3412 & 1647 & - & - \\
$\mathrm{Cu}-\mathrm{L}_{3}$ & 1603 & 3410 & - & 577 & 422 \\
$\mathrm{Mn}-\mathrm{L}_{3}$ & 1605 & 3350 & - & 548 & 469 \\
$\mathrm{Zn}-\mathrm{L}_{3}$ & 1619 & 3359 & - & 551 & 471 \\
\hline
\end{tabular}

The IR spectrum of the ligand $\mathrm{L}_{3}$ exhibited a strong and sharp band at $1647 \mathrm{~cm}^{-1}$ assigned to $\mathrm{v}(\mathrm{C}=\mathrm{O})$, while this band was absent in the spectra of the complexes indicated that the coordination of the metal ion was through the carbonyl oxygen of pyrazolone as well as the atom nitrogen of the $\mathrm{C}=\mathrm{N}$ and atom nitrogen of the $\mathrm{N}-\mathrm{H}$. This was also supported by the presence of the band at $577-548 \mathrm{~cm}^{-1}$ assigned to $\mathrm{v}(\mathrm{M}-\mathrm{O})$ and the band at $471-422 \mathrm{~cm}^{-1}$ assigned to $v(\mathrm{M}-\mathrm{N})$.

Antimicrobial activity: The average diameter data of inhibition zone of the ligands and complexes against Escherichia coli and Bacillus subtilis are listed in Table-3. The free ligands are more or less inactive against the two bacteria, the antibacterial activity of the ligands become more pronounced when it is coordinated to the metal ions. The biological activities of the all the complexes against $E$. coli follow the order: $\mathrm{Cu}-\mathrm{L}_{1}>\mathrm{Mn}-\mathrm{L}_{1}>\mathrm{Ni}-\mathrm{L}_{1}>\mathrm{CuL}_{2}>\mathrm{L}_{1}>$ amoxicillin $>\mathrm{Mn}-\mathrm{L}_{3}>$ $\mathrm{Cu}-\mathrm{L}_{3}>\mathrm{Mn}-\mathrm{L}_{2}>\mathrm{Zn}-\mathrm{L}_{2}>\mathrm{Zn}-\mathrm{L}_{3}>\mathrm{L}_{2}>\mathrm{L}_{3}$. The biological activities of the all the complexes against Bacillus subtilis follow the order: $\mathrm{Cu}-\mathrm{L}_{1}>\mathrm{Cu}-\mathrm{L}_{2}>$ amoxycillin $>\mathrm{Mn}-\mathrm{L}_{3}>$ $\mathrm{Ni}-\mathrm{L}_{1}>\mathrm{Mn}-\mathrm{L}_{1}>\mathrm{L}_{1}>\mathrm{L}_{3}>\mathrm{L}_{2}>\mathrm{Zn}-\mathrm{L}_{3}>\mathrm{Cu}-\mathrm{L}_{3}>\mathrm{Zn}-\mathrm{L}_{2}>\mathrm{Mn}-\mathrm{L}_{2}$. All the data showed that E. coli and Bacillus subtilis were inhibited to a greater degree by the $\mathrm{Cu}$ (II)- $\mathrm{L}_{1}$ complex, even greater than the contrasted amoxycillin.

\section{Conclusion}

In this study, we have presented the synthesis and characterization of three new ligands and their $\mathrm{Ni}(\mathrm{II}), \mathrm{Cu}(\mathrm{II}), \mathrm{Mn}(\mathrm{II})$ and $\mathrm{Zn}$ (II) complexes. The antibacterial properties of these compounds were also investigated.

\begin{tabular}{ccc}
\multicolumn{3}{c}{ TABLE-3 } \\
AVERAGE DIAMETER DATA OF INHIBITION \\
ZONE OF THE LIGANDS AND METAL COMPLEXES \\
\hline \multirow{3}{*}{ Compound } & \multicolumn{2}{c}{ Average diameter $(\mathrm{cm})$} \\
& (concentration: $5.00,2.50,1.25 \mathrm{mg} / \mathrm{mL}$ ) \\
\cline { 2 - 3 } & Escherichia coli & Bacillus subtilis \\
\hline $\mathrm{L}_{1}$ & $1.15 / 1.03 / 1.05$ & $-/ 1.03 / 1.00$ \\
$\mathrm{Cu} \mathrm{L}_{1}$ & $1.50 / 1.38 / 1.35$ & $1.97 / 1.40 / 1.00$ \\
$\mathrm{Mn}-\mathrm{L}_{1}$ & $1.28 / 1.12 / 0.98$ & $1.18 /-/-$ \\
$\mathrm{Ni}-\mathrm{L}_{1}$ & $1.12 / 1.35 / 1.33$ & $1.25 / 0.93 / 1.53$ \\
$\mathrm{~L}_{2}$ & $0.87 / 0.83 / 0.90$ & $-/ 0.85 / 1.05$ \\
$\mathrm{Cu}-\mathrm{L}_{2}$ & $1.23 / 1.22 / 1.12$ & $1.43 / 1.40 / 1.15$ \\
$\mathrm{Mn}-\mathrm{L}_{2}$ & $0.95 / 1.08 / 0.72$ & $-/-/ 0.83$ \\
$\mathrm{Zn}-\mathrm{L}_{2}$ & $-/ 1.08 /-$ & $-/ 0.90 /-$ \\
$\mathrm{L}_{3}$ & $0.89 / 0.82 / 0.81$ & $1.06 / 0.96 / 0.85$ \\
$\mathrm{Cu}-\mathrm{L}_{3}$ & $1.04 / 0.96 / 1.06$ & $0.81 / 0.92 / 0.83$ \\
$\mathrm{Mn}-\mathrm{L}_{3}$ & $1.12 / 0.83 / 0.81$ & $1.29 / 1.14 / 0.83$ \\
$\mathrm{Zn}-\mathrm{L}_{3}$ & $1.09 / 0.83 / 0.92$ & $0.91 / 0.98 / 0.88$ \\
$\mathrm{Amoxycillin}$ & $1.10 / 1.00 / 1.10$ & $1.40 / 1.25 / 1.35$ \\
\hline
\end{tabular}

\section{ACKNOWLEDGEMENTS}

The authors are grateful to the Department of Basic Science, Tianjin Agricultural College of China for providing available laboratory facilities. The authors are also grateful to the Science Development Commission of Tianjin Agricultural College (No: 2011N06).

\section{REFERENCES}

1. S.G. Reams, Arch. Microbiol., 167, 209 (1997).

2. J.Z. Li, W.J. Yu and G. Li, J. Appl. Chem., 17, 280 (2000).

3. J.M. Shi, F.X. Zhang, C.J. Wu and L.D. Liu, Acta Cryst., E61, m2320 (2005).

4. H.Q. Zhang, J.Z. Li, Y. Zhang and D. Zhang, Chin. J. Inorg. Chem., 24, 990 (2008).

5. A. Deep, S. Jain, P.C. Sharma, P. Verma, M. Kumar and C.P. Dora, Acta Polon. Pharm. Drug Res., 67, 255 (2010).

6. V. Mahalingam, N. Chitrapriya, M. Zeller and K. Natarajan, Polyhedron, 28, 1532 (2009).

7. X. Zhang, H.L. Wei, W.S. Liu, D.Q. Wang and X. Wang, Bioorg. Med. Chem. Lett., 17, 3774 (2007).

8. S. Gemma, G. Kukreja, C. Fattorusso, M. Persico, M.P. Romano, M. Altarelli, L. Savini, G. Campiani, E. Fattorusso, N. Basilico, D. Taramelli, V. Yardley and S. Butini, Bioorg. Med. Chem. Lett., 16, 5384 (2006).

9. B.S. Jansen, Acta Chem. Scand., 13, 16681959.

10. Z.G. Li, Synthesis of the Organic Intermediate, Beijing, Chemical Industry Press, pp. 152-153 (2000). 